Vol. 16 (2007): 79-88

\title{
Economic values of pork production related traits in Finland
}

\author{
Timo Serenius, Päivi Muhonen \\ MTT Agrifood Research Finland, Biotechnology and Food Research, FI-31600, Jokioinen, Finland, \\ e-mail: timo.serenius@mtt.fi
}

Kenneth Stalder

Iowa State University, Department of Animal Science, Ames, IA50011, USA

\begin{abstract}
The objective of the present study was to estimate economic values for sow efficiency and meat production traits in the Finnish pork production system including the consideration for subsidies. Economic values were estimated by developing a bio-economic model that describes the Finnish production system. Genetic improvement estimates for meat production traits were also developed in order to evaluate how much genetic gain is reduced due to selection for meat quality. Results showed that the highest economic values, when expressed in genetic standard deviations, were obtained for total number of piglets born $(€ 2.07$ per piglet), feed conversion ratio ( $€ 2.07$ per feed unit per $\mathrm{kg})$, and lean meat percentage $(€ 1.69$ per \%). Economic values for litter size, piglet mortality, sows length of productive life, and lean meat percentage increased when subsidies were not accounted for in the bio-economic model. Results show further that meat quality should have 15-20 percent weight in the Finnish production trait index in order to prevent its deterioration. When the selection weights are $15-20 \%$ for meat quality, the expected loss in genetic gain is approximately 3 percent for other production traits when compared to selection indices where meat quality traits are not included.
\end{abstract}

Key-words: Economic weight, efficiency, pig, total merit index

\section{Introduction}

The objective of pig breeding is to develop swine genetics such that producer's income will increase and/or the cost of meat production will decrease si- multaneously with improvement without a change in animal welfare and -robustness. Optimally, this goal will be reached, if selection is based on total merit index where traits included are properly weighted according to appropriate economic val- 
Serenius, T. et al. Economic values for pig traits

ues for each trait. Thus, it is important to have an accurate knowledge about the economic values for all of the traits that are economically important in pork meat production.

Typically, traits in pig breeding are classified into sow efficiency or maternal traits (prolificacy traits, sow longevity) and meat production or terminal traits (daily gain, feed conversion ratio, carcass quality, meat quality) (e.g. Ollivier 1998). In Finland, the production trait index has been divided into performance (35\% [35\% of variation in production trait index]), carcass quality (45\%), and meat quality (20\%) traits as is described by Faba Breeding (2007). Within the performance index, average daily gain has $46 \%$ of the total weight while feed conversation ratio has $54 \%$ of the total weighting. Proportional weights in the carcass quality index are $24 \%$ and $76 \%$ for fat- and meat percentages, respectively. These weights are based on the calculations reported by Kangasniemi (1996). Proportional trait weights within the meat quality index $(10 \%$ for loin $\mathrm{pH}, 35 \%$ for loin L* [luminance, measured with Minolta CR 300; CIE, 1971], 10\% for ham $\mathrm{pH}, 45$ for ham $\mathrm{L}^{*}$ ) are mainly based on objectives set for different meat quality traits.

Since 2003, the traits (and approximate relative weighting) included in the Finnish prolificacy (reproductive) index have been total number of piglets born $(44 \%)$, number of stillborn piglets $(16 \%)$, piglet mortality during suckling $(20 \%)$, age at first farrowing $(10 \%)$, and farrowing interval (10\%) (Serenius 2004, Faba Breeding 2007). Although numerous traits are already included in the prolificacy index, one could argue that other traits like sow longevity should be included in the breeding program. Earlier studies have shown that sow longevity is moderately heritable (Serenius et al. 2006), and thus, genetic improvement is possible to obtain in an efficient swine breeding program. After Finland joined the European Union (EU), there has been a great deal of change in agricultural policy, and thus, economic weights should be evaluated and updated to reflect the current (or future) economic situation for Finnish pork meat production. For example, subsidies do have an affect on economy of pork meat production, and thus, economic values of different traits may be dependent on subsidy policy. Moreover, selection for meat quality has been successful such that current meat quality values are close to optimal (SevónAimonen and Mäki-Tanila 2005). Thus, economic weighting for the meat quality traits should be set so that the traits remain unchanged or alternatively genetic selection goal should target slightly darker meat (smaller L* values) during the next few generations of selection.

As stated above, there are many unanswered questions relating to the economic values for economically important traits in pork meat production. Thus, this study was conducted to estimate economic values for sow efficiency and meat production traits in the Finnish production system using bio-economic modeling. Moreover, genetic improvement estimates of meat quality and meat production traits were developed in order to evaluate how much genetic gain is reduced due to simultaneous selection for meat quality and other production traits when compared to selection when the meat quality traits are excluded from the models.

\section{Material and methods}

\section{Model description}

A bio-economic model was developed to describe lifetime production of 100 purchased commercial females (Landrace $\times$ Large White crosses) and their offspring. The model was similar to the one previously described by De Vries (1989). Lifetime production was followed for 10 parities, after which all remaining sows were harvested. In each cycle, sow culling was simulated according to the frequencies calculated from actual data provided by Faba Breeding (Table 1). Between parity differences of litter size and piglet mortality were simulated according to parity solutions from the current breeding value estimation done at Faba Breeding.

Daily feed intake during gestation and lactation were implemented using the values summarized by Siljander-Rasi et al. (2006): basic sow 
Vol. 16 (2007): 79-88

feed intake was assumed to be $2.4 \mathrm{~kg}$ per day. In addition, feed intake was assumed to increase by 0.015 and $0.6 \mathrm{~kg}$ per day per piglet during gestation and lactation, respectively.

Growth period of farrow-finishers was divided to three phases. The first phase was from birth to weaning, the second one was from weaning to $25 \mathrm{~kg}$ of live weight and the last phase was from $25 \mathrm{~kg}$ to harvest $(110 \mathrm{~kg})$. The assumed feed consumption and daily gain in these phases are presented in Table 2.

Feed and facility prices used in the present study are shown in Table 3. The feed prices were obtained from ProAgria Kymenlaakso, and they represent average prices for complete feed commercially produced at the farms belonging to the management and economic recording scheme (Ari Nopanen, ProAgria Kymenlaakso, personal communication). The cost for different pig facilities were determined from the building cost guide given by the Ministry of Agriculture. Financing for the facilities assumed the producers had loans payable over a 15 year period at a 5 percent interest rate. Utilized daily prices including building costs, interest rate, energy for heating and lighting, insurance, routine work, etc, were $€ 1.25$ and $€ 0.24$ in sow unit and growing-finishing unit, respectively.

Table 1. Culling of sows, total number of piglets born, proportion of stillborn piglet and piglet mortality in the suckling period at parities 1-10 (P1-P10) used in the current bio-economic model.

\begin{tabular}{|c|c|c|c|c|c|c|c|c|c|c|}
\hline & P1 & $\mathrm{P} 2$ & P3 & $\mathrm{P} 4$ & P5 & P6 & P7 & P8 & P9 & $\mathrm{P} 10$ \\
\hline Sow culling, $\%$ & 12 & 22 & 18 & 19 & 21 & 23 & 28 & 35 & 39 & 44 \\
\hline Total number of piglets born & 11.2 & 12.1 & 13.0 & 13.2 & 13.3 & 13.2 & 13.0 & 12.8 & 12.4 & 12.2 \\
\hline Proportion of stillborn piglets, $\%$ & 8 & 8 & 8 & 9 & 11 & 12 & 12 & 13 & 14 & 15 \\
\hline $\begin{array}{l}\text { Piglet mortality in the suckling } \\
\text { period, \% }\end{array}$ & 10 & 10 & 12 & 13 & 14 & 14 & 15 & 15 & 15 & 15 \\
\hline
\end{tabular}

Table 2. Piglet production related biological and economic parameters utilized in a bio-economical model for the Finnish commercial sow facilities.

\begin{tabular}{lc}
\hline Cause of cost per trait & Average value \\
\hline Cost of purchased gilt & $€ 170$ \\
Basic non-feed cost per day, gilts & $€ 1.04$ \\
Basic non-feed cost per day, sows & $€ 1.25$ \\
Insemination costs per parity & $€ 30$ \\
Basic feed intake per sow per day & $2.4 \mathrm{~kg}$ \\
Extra feed intake per gestation per piglet & $1.7 \mathrm{~kg}$ \\
Extra feed intake per day of lactation per piglet & $0.6 \mathrm{~kg}$ \\
Feed price & $€ 0.23 \mathrm{~kg}^{-1}$ \\
\hline
\end{tabular}

Table 3. Biological and economic parameters utilized in the farrow-finishing phase.

\begin{tabular}{lccc}
\hline & $\begin{array}{c}\text { Stage 1 } \\
\text { Birth-weaning }\end{array}$ & $\begin{array}{c}\text { Stage 2 } \\
\text { Weaning-25 kg }\end{array}$ & $\begin{array}{c}\text { Stage 3 } \\
\text { 25 kg-slaughtering }\end{array}$ \\
\hline Daily gain (g per day) & 230 & 470 & 900 \\
Feed intake (g per day) & 30 & 800 & 2250 \\
Feed price (€ per kg) & 0.45 & 0.33 & 0.20 \\
Non-feed cost $(€$ per day) & & 0.125 & 0.24 \\
Extra non-feed cost (€ per slaughtering) & & & 2.15 \\
\hline
\end{tabular}


Serenius, T. et al. Economic values for pig traits

\section{Calculation of economic values}

Calculation of economic values was based on the change in economic efficiency with one unit change of a trait under consideration. First, economic efficiency of meat production was calculated in a basic situation with biological and economical parameter assumptions. The economic efficiency was determined as a cost per kg pork meat produced:

\section{efficiency $=$ production costs $/$ meat produced,}

where meat produced describes the amount of pork meat produced. Production costs were divided into the costs of piglet production, and to the costs of fattener pig (from $25 \mathrm{~kg}$ to slaughtering) production.

After the economic efficiency in the basic situation of all initial production and cost assumptions was estimated, economic values for each trait studied (one trait at a time) were determined by calculating economic efficiency by improving each individual trait under consideration. The economic value of each individual trait was then calculated as a proportion of the change in efficiency that occurred when the trait being evaluated changed by one unit:

economic value $=\Delta$ efficiency $/ \Delta$ trait,

where $\Delta$ corresponds to the change in efficiency or trait. Thus, economic value of a trait is measured as decrease in the cost of pork meat production after one unit improvement in a trait under consideration. Economic values are presented in slaughter pig basis.

Economic values were calculated by accounting, and not accounting for subsidies in the bioeconomic model. When accounting for subsidies, they were set to decrease the costs of pork meat production. The subsidies were assumed to be paid per sow alive ( $€ 215$ per sow per year) and per carcass harvested ( $€ 22$ per carcass). Moreover, sensitivity analysis were carried out by comparing relative economic values in the situations where feed prices were decreased or increased by $20 \%$, or production level of total number born, average daily gain, or lean meat percentage was improved by one phenotypic standard deviation.

\section{Traits studied}

The traits studied are divided into sow efficiency or maternal traits (total number of piglets born, number of stillborn piglets, piglet loss during nursing, age at first farrowing, extra days between farrowings, and length of productive life) and production of terminal traits (average daily gain [25-100 kg], feed conversion ratio, lean meat percentage).

To reliably estimate economic value for meat quality ( $\mathrm{pH}$, color, etc), its association both with weight loss (largely water loss from the carcass and individual pork cuts), and consumers' shopping behavior should be known. In the current study, there was no chance to study these associations, and thus, it was not possible to calculate economic values for meat quality directly. However, pseudo BLUP (Wray and Hill 1989) was built to examine how much selection for meat quality traits will cost in terms of the decrease in the response in daily gain, feed conversion ratio, and lean meat percentage. Weighting among meat quality traits was the same as those utilized in the present Finnish breeding program $(11 \%$ for loin $\mathrm{pH}, 35 \%$ for loin $\mathrm{L}^{*}, 11 \%$ for ham $\mathrm{pH}, 45 \%$ for ham $\mathrm{L}^{*}$ ) (Faba Breeding 2007). Different proportions of weighting (0, $5,10,15,20,25,30 \%)$ for the meat quality index out from the total production trait index were studied. The genetic parameters utilized (Table 4) are based on the study by Sevón-Aimonen and MäkiTanila (2005), and the (co)variance parameters utilized in the Finnish swine breeding value estimation. The pseudo BLUP was implemented using the program SelAction (Rutten et al. 2002).

Population characteristics were derived to describe the national Finnish pig breeding system (Serenius et al. 1999). The breeding program was assumed to be based on 550 sows and 110 boars selected annually. Moreover, it was assumed that each boar is mated with five sows, and each litter consists of four male and four female piglets. From each litter, two boars and one castrate were 
Vol. 16 (2007): 79-88

assumed to be raised at a test station. Thus, it was assumed that breeding values (BLUP) of boar selection were based on the animals own information for average daily gain and feed conversion ratio, and half/fullsib information for the meat and carcass quality traits. The breeding values for all sow traits were assumed to be based on half/fullsib information.

\section{Results}

In the basic situation, when subsidies were accounted for, the economic efficiency (costs of meat production) of pork meat production using current bio-economic model was $€ 1.19$ per $\mathrm{kg}$. Similarly, the cost of $25 \mathrm{~kg}$ piglet was 50.8 euros. When subsidies were removed from the economic situation, the economic efficiency and costs of piglet production were $€ 1.62$ per $\mathrm{kg}$ and $€ 61.8$ per piglet, respectively.

Economic values estimated are presented in Table 5. All the economic values are presented in slaughter pig basis. The second and third column values are presented in each trait's particular unit of measure, and fifth and sixth column values are standardized to one genetic standard deviation of each trait. The greatest economic value, in measured units, was obtained for feed conversion ratio: cost of pork meat production will decrease by $€ 17.26$ per pig slaughtered, if each pig will consume one feed unit less per one $\mathrm{kg}$ of growth.

Table 4. Heritabilities (diagonal), genetic (upper triangle) and phenotypic (lower triangle) correlations for ultimate $\mathrm{pH}$ and $\mathrm{L}^{*}$ (loin and ham), average daily gain (ADG), feed conversion ratio (FCR), and lean meat percentage (meat-\%) utilized in pseudo BLUP calculations.

\begin{tabular}{lccccccc}
\hline & PH, loin & L, loin & PH, ham & L, ham & ADG & FCR & meat-\% \\
\hline pH, loin & 0.16 & -0.77 & 0.9 & -0.28 & 0 & 0 & -0.3 \\
L, loin & -0.58 & 0.25 & -0.74 & 0.67 & 0.08 & -0.04 & 0.28 \\
pH, ham & 0.58 & -0.39 & 0.22 & -0.45 & 0.09 & 0 & -0.4 \\
L, ham & -0.19 & 0.33 & -0.15 & 0.10 & 0.06 & -0.04 & 0.24 \\
ADG & -0.06 & 0.06 & -0.02 & 0.05 & 0.36 & -0.6 & -0.1 \\
FCR & 0 & -0.04 & 0 & -0.04 & -0.5 & 0.58 & -0.45 \\
meat-\% & -0.09 & 0.13 & -0.12 & 0.06 & -0.16 & -0.45 & 0.43 \\
\hline
\end{tabular}

Table 5. Estimated economic values for prolificacy and production traits in the Finnish pork meat production system.

\begin{tabular}{|c|c|c|c|c|c|}
\hline & \multicolumn{2}{|c|}{$€^{\mathrm{a}}$} & \multirow[t]{2}{*}{$\sigma_{g}$} & \multicolumn{2}{|c|}{$€$ per $\sigma_{\mathrm{g}}^{\mathrm{a}}$} \\
\hline & $\mathrm{S}^{\mathrm{b}}$ & No $S^{b}$ & & $\mathrm{~S}^{\mathrm{b}}$ & No $S^{b}$ \\
\hline Number of piglets born, piglet & 2.433 & 3.415 & 0.85 & 2.07 & 2.90 \\
\hline Number of stillborn piglets, piglet & -2.681 & -3.763 & 0.34 & -0.91 & -1.28 \\
\hline Piglet mortality, piglet & -3.163 & -4.417 & 0.32 & -1.01 & -1.41 \\
\hline Age at $1^{\text {st }}$ farrowing, day & -0.050 & -0.050 & 17.9 & -0.90 & -0.90 \\
\hline Extra days between farrowings, day & -0.187 & -0.187 & 6.32 & -1.18 & -1.18 \\
\hline Length of productive life, day & 0.009 & 0.014 & 35.9 & 0.32 & 0.50 \\
\hline Daily gain, $\mathrm{kg}$ & 0.025 & 0.026 & 58.4 & 1.46 & 1.52 \\
\hline Feed conversion ratio, fu kg ${ }^{-1}$ & 17.26 & 17.26 & 0.12 & 2.07 & 2.07 \\
\hline Lean meat $\%, \%$-unit & 1.644 & 2.225 & 1.03 & 1.69 & 2.29 \\
\hline
\end{tabular}

${ }^{\mathrm{a}}$ Economic values are presented both in measure units (Euro) and as scaled values to one genetic standard deviation

$\left(\sigma_{\mathrm{g}} ; €\right.$ per $\left.\sigma_{\mathrm{g}}\right)$

${ }^{\mathrm{b}}$ Economic values are calculated both by accounting for (S) and not accounting for (No S) subsidies 
Serenius, T. et al. Economic values for pig traits

Table 6. Predicted genetic improvement of production- and meat quality traits with different economic weighting $(0-30 \%)$ for meat quality in production trait index used to evaluate Finnish breeding scheme.

\begin{tabular}{llcccccc}
\hline & \multicolumn{7}{c}{ Proportional weight of meat quality, \% } \\
\cline { 2 - 7 } & 0 & 5 & 10 & 15 & 20 & 25 & 30 \\
\hline Daily gain, g per day & 27.9 & 28.0 & 28.1 & 28.1 & 27.9 & 27.7 & 27.2 \\
Feed conversion ratio, fu kg-1 & -0.08 & -0.08 & -0.08 & -0.08 & -0.08 & -0.08 & -0.08 \\
Lean meat -\% & 61.9 & 61.1 & 59.9 & 58.4 & 56.4 & 53.9 & 50.7 \\
pH, loin & -0.005 & -0.004 & -0.002 & -0.001 & 0.000 & 0.002 & 0.004 \\
Luminance, loin & 0.172 & 0.135 & 0.093 & 0.044 & -0.010 & -0.072 & -0.139 \\
pH, ham & -0.006 & -0.004 & -0.003 & -0.001 & 0.000 & 0.003 & 0.005 \\
Luminance, ham & 0.108 & 0.085 & 0.060 & 0.030 & -0.03 & -0.040 & -0.081 \\
\hline
\end{tabular}

Moreover, the economic value for feed conversion ratio was the same, regardless if subsidies were or were not included in the calculations. Additionally, the economic value for extra days between farrowings (increasing farrowing interval one day) and age at first farrowing were the same $(€-0.19$ per day and $€-0.05$ per day) when subsidies were and were not accounted for in the bio-economic model. For all the other traits, economic values were higher in the unsubsidized production.

Among the litter size related traits, the economic value was smallest for the total number of piglets born ( $€ 2.43$ per piglet and $€ 3.42$ per piglet when subsidies were and were not accounted for, respectively), and largest for piglet mortality between birth and weaning ( $€-3.16$ and $€-4.42$ per piglet). Among the sow efficiency related traits measured in days, the economic value was largest for extra days between farrowings ( $€-0.18$ per day), and smallest for the length of productive life (€0.009 per day when subsidies were accounted for, and $€ 0.014$ when they were not accounted for).

The total number of piglets born, daily gain, feed conversion ratio, and lean meat- $\%$ were the most valuable traits, when economic values were scaled to genetic standard deviation (Table 5). Among these traits, the total number of piglets born and feed conversion ratio had the highest economic value ( $€ 2.07$ per $\sigma_{g}$ ) when subsidies were accounted for in the calculations, and total number of piglets born had the highest economic value when subsidies were not accounted for $\left(€ 2.90\right.$ per $\left.\sigma_{\mathrm{g}}\right)$.

Results from sensitivity analyses show that the economic values of fattener pig traits are more sensitive to changes in bio-economic model parameters than the economic values of maternal traits (Fig. 1). The one standard deviation unit change in litter size has the most visible effect on proportional economic weighing of total merit index on all of the traits studied.

The estimated genetic improvement for daily gain, feed conversion ratio, lean meat $\%$, and meat quality traits $\left(\mathrm{pH}, \mathrm{L}^{*}\right)$ obtained using different economic values for meat quality are presented in Table 6. Genetic improvements are rel-

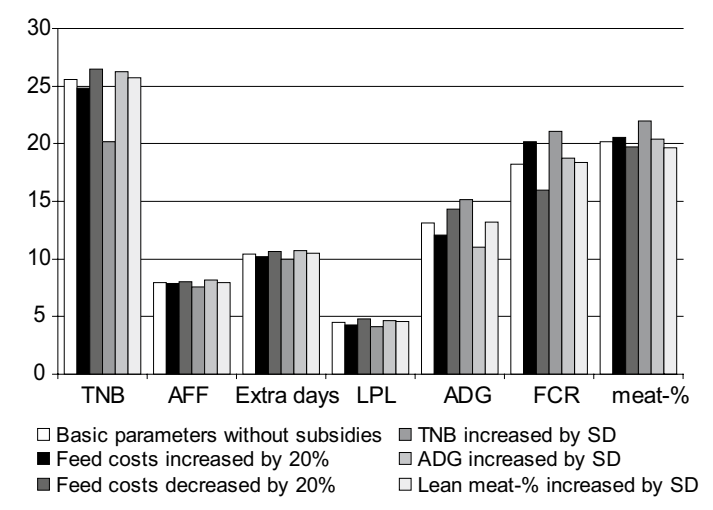

Fig. 1. Proportional weighing of total number of piglets born (TNB), age at first farrowing (AFF), extra days between farrowings, length of productive life (LPL), average daily gain (ADG), feed conversion ratio (FCR), and lean meat percent (meat-\%) with basic parameters and when feed costs have been decreased and increased by $20 \%$, or when average of TNB, ADG and meat- $\%$ has been increased by one phenotypic standard deviation (SD). 
Vol. 16 (2007): 79-88

ative to one standard deviation increment of production trait index. Results show that meat quality should have some $15-20 \%$ weight to prevent the decrease in muscle $\mathrm{pH}$, and the increase in muscle $L^{*}$ values.

\section{Discussion}

\section{Basic model}

Calculation of the economic weights in the current study was based on the bio-economic model that had a starting point of purchasing 100 gilts, and then followed their production over ten parities. Economic values were based on economic efficiency, i.e., economic values are expressed as net changes in production costs per kg of meat produced. The model for the Finnish pork production was satisfactory when assessed in the prices obtained for piglet and meat production. When subsidies were not accounted for, the price for one $\mathrm{kg}$ of meat produced was $€ 1.19$, and similarly the piglet price was $€ 50.8$. According to the price statistics on agricultural products (TIKE 2006), these agree relatively well with the piglet and pork meat production prices of 2005 in Finland.

When subsidies were not accounted for, the economic efficiency and costs of piglet production were $€ 1.62$ per $\mathrm{kg}$ and $€ 61.8$ per piglet, respectively. Thus, according to these values, and the current price level in Finland, pork producers have relatively poor chance to survive in pork business without subsidies. Either production costs have to be decreased or price per kg of pork meat slaughtered has to be increased, if subsidies are lowered or totally removed. On the other hand, there has been speculation, that production is not optimized when subsidies exist. For example, the subsidies paid to Finnish pork producers are based on the number of sows alive. Thus, currently it may be economically more efficient for individual pork producer to keep all the sows rather than to replace the poor producing ones.

It is not clear whether subsidies should be in- cluded in the models when calculating economic values. This is because it is not clear if subsidies in the future will stay in the current form, or in different form, or if they will disappear totally. In any case, they do have an effect on economic values, and the economic situation experienced by Finnish pork producers. In general, the economic values for the traits that do impact the total amount of pork meat produced (total number of piglets born, number of stillborn piglets, piglet mortality during suckling, sow's length of productive life, and lean meat \%) are higher when subsidies are not accounted for. In reality, the economic value for many other traits may also be influenced by the change in subsidy policy. For example, if feed prices will change due to subsidy policy, they will immediately be reflected in the economic value of feed conversion ratio.

Animal well being issues should be remembered in the discussion on economic efficiency of pork meat production. For example, one has to keep in mind that the cost of a sow unit increases with the increasing space needed per sow or farrow-finisher. Thus, if Finland or Nordic countries want to have tight animal welfare restrictions, some other institution than producer should pay the extra costs due to welfare policy. Moreover, consumers may be willing to pay the extra price, if the whole production chain would utilize the fact of growing pigs under high animal welfare conditions as marketing tool and inform consumers that the pork has had "happy life".

\section{Estimated economic values}

Economic values were presented both in the actual units each trait is measured and in genetic standard deviation units. The values presented in the actual units of measure describe how much a producer can improve efficiency of production by improving management, facilities, genetics, or any factor having impact on production level. When comparing these values, one should remember the unit of trait values, and to realize how realistic it is to improve one full unit by changing e.g. management 


\section{AGRICULTURAL AND FOOD SCIENCE}

Serenius, T. et al. Economic values for pig traits

routines. The values expressed in standard deviation units reflect the relative proportions the traits should be weighted in a breeding program. Scaling is important in order to compare the potential or improving economic efficiency of pork meat production by an effective breeding, selection, and mating system program. If there is no genetic variation in a trait, there is no sense to include it in the breeding program - no matter what the economic value of a trait is.

Based on the economic values of traits presented in the actual units of measure, feed conversion ratio has the clearest effect on economic efficiency of pork production. One should keep in mind, however, that the economic value of feed conversion ratio is very sensitive to the price of feed. In other words, producers can improve the economics of production simply by producing feed on-farm, by negotiating prices with feed providers, or utilizing other grain marketing strategies designed to reduce the feed costs.

The litter size related traits (total number of piglet born, number of stillborn piglets, and piglet mortality during suckling) and lean meat content showed also clear economic value in their actual units of measure. Interestingly, the economic value for piglet survival (both in farrowing and before weaning) is higher than for total number of piglets born. This is because extra piglet born has caused expenses through extra feed consumption by sow and piglet. If the extra piglet does not survive to produce an additional extra pig slaughtered, the extra economic inputs do not result in extra output, and hence, neither income to the producer. Moreover, Quinton et al. (2006) showed that if there is non-linear environmental relationship between total number of piglets born and piglet mortality, the difference in economic weight (higher economic weight for piglet survival) is even more pronounced for higher litter size.

Total number of piglets born, daily gain, feed conversion ratio, and lean meat- $\%$ were found to be the most valuable traits, when economic values are scaled to the genetic standard deviation of the traits. Of these traits, total number of piglets born and feed conversion ratio had the highest economic value $\left(€ 2.07\right.$ per $\left.\sigma_{\mathrm{g}}\right)$ when subsidies were accounted for in the calculations, and total number of piglets born had the highest economic value when subsidies were not accounted for $\left(€ 2.90\right.$ per $\sigma_{\mathrm{g}}$ ). In general, these traits have resulted in the greatest economic values in the earlier studies as well (e.g. Ollivier 1998). A detailed comparison of economic values from different studies is difficult due to changes in feed prices and other expenses. For example, Houska et al. (2004) reported the economic value of litter size in Czech Republic would be 1.68 times greater if carcass price would increase by $20 \%$. They indicated also that the economic values of average daily gain and weight of valuable cuts would be clearly higher if the number of piglets born alive would be one standard deviation larger. In the current study, one standard deviation increment in the total number of piglets born also clearly increased the proportional weighing of fattener pig traits. Our results indicated further that the economic value of litter size will decrease if the average number of piglets born will increase.

\section{Total merit index in practice}

Although it is possible to determine economic values for different traits, it is not easy to determine the proper weights in total merit index. This is because (i) economic weights are based on the prices and production level of today or in the past, whereas they should reflect the values ten years ahead, and (ii) some of the traits have so called 'social value'. Meat quality is a good example of a trait known to have both economic and social value. Economic value comes from weight loss etc., whereas social value is a result of consumers' willingness to buy and pay more for pork having superior quality characteristics.

In the current study, no economic values for meat quality traits were estimated per se, but selection index was developed to mirror how genetic improvement of feed conversion ratio, daily gain and lean meat percent is affected by different weights of meat quality in total merit index. Results indicate that meat quality should have 
Vol. 16 (2007): 79-88

15-20 percent proportional weight in production trait index if we want to eliminate its deterioration due to unfavorable genetic associations with other traits in the index. When the economic weight for meat quality was set to zero, and the economic values were based on the situation where subsidies were not accounted for, the value of genetic gain for feed conversion ratio, daily gain and lean meat percentage was $€ 3.10$ per carcass slaughtered per one standard deviation improvement of selection index. If the proportional weight for meat quality in the total merit index was 20 percent, the corresponding economic improvement is $€ 3.01$. Thus, the cost of having 20 percent weighting on meat quality in the total production trait index is $€ 0.09$ (2.9\%). This does not appear to be a dramatic change - fortunately the unfavorable genetic correlations between meat quality and other economically important traits are relatively small. Thus, we do suggest that some weight for meat quality is included in the total production trait index such that current level of meat quality is maintained or even slightly improved.

Another trait having both economic and social value is sow longevity (length of productive life). The authors argue that society, at least in northern Europe, is not going to accept a pork meat production system that is based on sows that cannot handle the stress of a normal production system. However, it is fortunate that sow longevity and prolificacy traits are genetically favorably correlated (Serenius et al. 2006). Thus, by proper weighting of prolificacy and sow longevity in the total merit index, it is possible to maintain or even improve sow longevity through an effective breeding program and implementing a sound mating system.

When evaluating the economic values for litter size related traits (total number of piglets born, number of stillborn piglets, piglet loss during suckling), double counting should be avoided. Breeding objective for all these traits is to increase the number of piglets weaned. Thus, the economic weight in the total merit index should be for the number of piglet weaned, and the three traits should be weighted accordingly their economic values. The economic value for number of piglets weaned can be calculated by dividing the econom- ic value of the total number of piglets born $(2.43$ when subsidies were accounted for, and 3.42 when they were not accounted for) by the proportion of weaned piglets out of the total number of piglets born (0.79). In the current bio-economic model, the economic value for number of piglet weaned is $€ 3.08$ when subsidies are accounted for in the model, and $€ 4.32$ when they are not accounted for. When genetic standard deviation of piglets weaned is 0.64 (Serenius et al. 2004), the economic value per genetic standard deviation for piglet weaned is 1.97 and 2.76 when subsidies are or are not accounted for in the calculations, respectively.

The Finnish pig breeding industry can utilize the current results, and adjust the economic weights in sow efficiency and production trait indices. However, gene flow methodology should be applied to further study the proportional weighting of the economic values for sow efficiency and meat production traits in total merit index. These proportional weighing factors heavily depend on the population structure, and crossbreeding program utilized (Wolfova and Nitter 2004). These calculations are needed if separate maternal and paternal lines are maintained and developed in the future in Finland.

\section{References}

CIE. 1971. Calorimetry, official recommendations of the international commission on illumination. Pub. No. 15 (E-1.3.1), Paris, France.

De Vries, A.G. 1989. A model to estimate economic values of traits in pig breeding. Livestock Production Science 21: 49-66.

Faba Breeding. 2007. Sikojen jalostusarvostelu. Cited 8.1.2007. Available on the internet: http://www.faba.fi/ jalostus/siat/jalostustoiminta/.

Houska, L., Wolfova, M. \& Fiedler, J. 2004. Economic weights for production and reproduction traits of pigs in the Chech Republic. Livestock Production Science 85: 209-221.

Kangasniemi, R. 1996. F-indeksi on uudistettu. Sika 5: 14-16.

Ollivier, L. 1998. Genetic Improvement of the Pig. In: Rothschild, M.F. \& Ruvinsky, A. (ed.). The genetics of the pig, Wallingford, Oxon, UK: Cab International. p. 511-540.

Rutten, M.J.M., Bijma, P., Woolliams, J.A. \& Arendonk, J.A.M. van. 2002. SelAction: Software to predict selec- 
Serenius, T. et al. Economic values for pig traits

tion response and rate of inbreeding in livestock breeding programs. Journal of Heredity 93: 456-458.

Serenius, T. 2004. Genetics of Sow Efficiency in the Finnish Landrace and Large White Populations. Agrifood Research Reports 55, 92 p.

Serenius, T., Sevón-Aimonen, M.-L., Kause, A., Mäntysaari, E.A. \& Mäki-Tanila, A. 2004. Selection potential of different prolificacy traits in the Finnish Landrace and Large White populations. Acta Agriculturae Scandinavica, Section A, Animal Science 54: 36-43.

Serenius, T., Sevón-Aimonen, M.-L. \& Mäki-Tanila, A. 1999. Efficient use of test capacity in pig breeding. In: J.A.M. van Arendonk (Eds). Book of Abstracts of the 50th Annual Meeting of the European Association for Animal Production. Zurich, Switzerland, p. 34.

Serenius, T., Stalder, K.J. \& Fernando, R.L. 2006. Genetic associations of length of productive life with age at first ferrowing and leg soundness score in Finnish Landrace population. In: Proceedings of the 8th World Congress on Genetics Applied to Livestock Production, August
13-18, 2006, Belo Horizonte, MG, Brasil. 4 p.

Sevón-Aimonen, M-L. \& Mäki-Tanila, A. 2005. Genetic parameters for meat quality and production traits in Finnish Landrace and Large White pigs. Book of Abstracts of the 56th Annual Meeting of the European Association for Animal Production. Uppsala, Sweden, p. 219.

Siljander-Rasi, H., Nopanen, A. \& Helin, J. 2006. Sian ruokinta ja hoito. Tieto Tuottamaan 114, $93 \mathrm{p}$.

TIKE, 2006. Hintapuntari 9/2006. Cited 8.1.2007. Available on the internet: http://www.matilda.fi/servlet/page?_pageid $=522,193 \&$ \&_dad $=$ portal30\& schema=PORTAL30

Quinton, V.M., Wilton, J.W., Robinson, J.A. \& Mathur, P.K. 2006. Economic weights for sow productivity traits in nucleus pig populations. Livestock Science 99: 69-77.

Wolfova, M. \& Nitter, G. 2004. Relative economic weights of maternal versus direct traits in breeding schemes. Livestock Production Science 88: 117-127.

Wray, N.R. \& Hill, W.G. 1989. Asymptotic rates of response from index selection. Animal Production 49: 217-227.

\title{
SELOSTUS
}

\section{Ominaisuuksien taloudelliset arvot suomalaisessa sianlihantuotannossa}

\author{
Timo Serenius, Päivi Muhonen, Kenneth J. Stalder \\ MTT Biotekniikka ja elintarviketutkimus ja Iowa State University
}

Tämän tutkimuksen tarkoituksena oli määrittää sianjalostuksessa käytettävän kokonaisjalostusarvon taloudelliset arvot suomalaisessa tuotantojärjestelmässä. Sitä varten luotiin biologis-taloudellinen malli, johon sisällytettiin sianlihantuotannon kustannukset porsastuotannosta teurastukseen. Tuotanto- ja hedelmällisyysominaisuuksien sekä ruhon laatuominaisuuksien taloudellisen arvon laskenta perustui taloudellisen tehokkuuden kasvuun. Lihan laadun valintapainoa tarkasteltiin tuotanto-ominaisuuksien ja ruhon laatuominaisuuksissa tapahtuvan perinnöllisen edistymisen heikkenemisen kautta.

Tulokset osoittivat, että pahnuekoolla (2,07 euroa/ syntynyt porsas), rehun muuntosuhteella (2,07 euroa/ry/ $\mathrm{kg})$ ja ruhon lihaprosentilla (1,69 euroa/prosentti) tulee olla kokonaisjalostusarvossa suurin taloudellinen paino. Myös tuotannon rakenteella ja tuotantotasoilla on vaikutusta ominaisuuksien taloudellisiin arvoihin. Esimerkiksi pahnuekoon, porsaskuolleisuuden, emakon kestävyyden ja ruhon lihaprosentin taloudelliset arvot kasvoivat, kun tuotantotukia ei otettu biologis-taloudellisessa mallissa huomioon. Perinnöllisen edistymisen ennusteiden tarkastelu osoitti, että lihan laadulla tulisi olla 15-20 prosentin painotus tuotanto-ominaisuusindeksissä, jotta laatu pysyisi nykyisellä tasolla tai hieman paranisi. Tällä painotuksella muiden tuotanto-ominaisuuksien perinnöllinen edistyminen on noin kolme prosenttia pienempi verrattuna tilanteeseen, jossa lihan laatua ei jalostettaisi lainkaan. 